\title{
A STUDY OF THE PERFORMANCE AND CHARACTERIZATIONS OF CLEANUP FLUIDS FOR RESERVOIRS DRILLED BY USING OIL-BASED MUDS
}

\author{
Ali Elsaeh Enbaia ${ }^{1, *}$ and Salah Musa Algarmadi ${ }^{2}$ \\ ${ }^{1}$ Petroleum Engineering Department, School of Engineering and Sciences, Curtin University. CDT \\ 250, 98009, Miri, Sarawak, Malaysia \\ ${ }^{2}$ Geology Department, Faculty of Sciences, Liverpool University, Liverpool, United Kingdom, \\ Email address: s.elgarmadi@liv.ac.uk
}

Received 11 October 2012; accepted 5 December 2012

\begin{abstract}
The correct selection of the reservoir drilling fluid is critical to achieve the ultimate aim of minimizing formation damage for the completed such wellbores.

This study evaluates the performance of a standard Oil Based Mud (OBM) to drill horizontal wellbores, concentrating on its formation damage characteristics and the Flow Initiation Pressures (FIP) required for production to flow through the filter-cake. For heterogeneous reservoirs, the study shows that in low permeability rocks the damage is relatively low but the FIP is high. Conversely, for high permeability rocks the FIP is low but formation damage is relatively high. If the drawdown pressure available from the reservoir is low, then we have the scenario where inflow will occur predominantly from the higher permeability formations which could be badly damaged but little inflow will occur from the relatively undamaged lower permeability rocks. In terms of maximizing production, this is obviously a less than optimal scenario.

With this in mind, evaluations were conducted of cleanup fluids to gauge their effect on lowering the FIP of the OBM filter-cake. Various fluids were screened for their mud removal performance which would potentially indicate good OBM 'chemical breakers'. Mud parameters such as oil: water ratio, base oil type and emulsifier content all affected the efficiency of the cleanup fluids. The best cleanup fluids were then utilized in a series of core tests to evaluate their effectiveness in reducing the filter-cake FIP.
\end{abstract}

\section{Introduction}

The increased inflow area offered by a horizontal wellbore over a vertical wellbore, and hence the greater productivity available, has lead to a large increase in the drilling and completing of horizontal wells. These wells are often completed with open-holes where screens either with or without gravel packs are used. In this context, where the ultimate goal of the drilling and completion phase is to minimize the skin and hence maximize productivity, the drilling fluid can have a major impact on achieving this aim.

Various laboratory evaluations of drilling fluid performance, in terms of the formation damage and flow initiation pressures, have been reported in the literature, Browne and Smith [1] and Ladva et al [2]. Although both Water Based Mud (WBM) and Oil Based Mud (OBM) results have been reported, there has been a relative emphasis on the former,

* Corresponding author.

E-mail address: enbaia1972@gmail.com 
A.E. Enbaia et al, A study of the performance and characterizations of cleanup fluids for reservoirs drilled by using oil-based muds, pp. $702-723$

particularly sized salt and polymer carbonate drilling fluids. It is the aim of this paper to assess both the formation damage and FIP for an OBM applied to a variety of reservoir rock permeability and assess the use of displacement/cleanup fluids. The performance advantages of OBM, such as the lubricity, shale stability and fluid loss and filter-cake characteristics, can make them particularly suitable for reservoir drilling applications. However, if the design of the completion phase involves the use of a water-based brine or gravel pack fluid, then the engineering of the fluids and displacement procedures will have a significant impact on the overall success of the completion (i.e. minimum skin).

The displacement efficiency will depend on both the hydrodynamic characteristics of the drilling and displacement fluids as well as the chemical interaction of the drilling and cleanup fluids. It is an aim of this paper to evaluate some of the properties of the drilling fluid which control the efficiency of these cleanup fluids. The cleanup fluids themselves are also evaluated for their efficiency in reducing the FIP needed to initiate flow from reservoir rocks. Where the FIP of the filter-cake is higher than the flowing pressure available from the reservoir, it will be necessary to reduce the filter-cake FIP to achieve inflow from as large a section as possible of the horizontal wellbore.

\section{OBM formation damage and FIP}

\subsection{Experimental methods}

To evaluate the formation damage and FIP for OBM in heterogeneous reservoirs, a variety of rock types covering a range of permeability was used as substrates in Table 1. Core plugs $25 \mathrm{~mm}$ in diameter and $30 \mathrm{~mm}$ in length were used throughout this study. The cores were vacuum saturated with brine, then flushed with Isopar L, a light refined mineral oil. The cores are brought to residual water saturation using Isopar L at a flow rate of 7.67 $\mathrm{ml} / \mathrm{min}$. For the formation damage and FIP tests the permeability of the cores was measured at imposed constant flow rates of 2, 4, and $6 \mathrm{ml} / \mathrm{min}$. For all the flow rates, the pressure drop across the core was measured by a pressure transducer fitted to the inlet of the core holder. The permeability of the core plugs is then calculated by plotting the pressure drop versus flow rate and curve fitting the data points.

\section{Table 1}

Sandstone used for producing core plugs utilized throughout this paper

\begin{tabular}{lc}
\hline \hline Rock Type & Typical Permeability Rang (to oil) (mD) \\
\hline Birchover & $5-15$ \\
Spynie & $30-50$ \\
Clashach A & $250-450$ \\
Clashach B & $500-850$ \\
Clashach C & $900-1500$ \\
Synthetic A & $2000-3000$ \\
Synthetic B & $4000-8000$ \\
\hline \hline
\end{tabular}

Journal of Engineering Sciences, Assiut University, Faculty of Engineering, Vol. 41, No. 2, March, 2013, E-mail address: jes@aun.edu.eg 
A.E. Enbaia et al, A study of the performance and characterizations of cleanup fluids for reservoirs drilled by using oil-based muds, pp. $702-723$

After the measurement of the initial permeability of the core plug, the drilling fluid was then placed in the cell and the core exposed to the mud under the following conditions:

- Temperature: $180^{\circ} \mathrm{F}$

- Differential Pressure: 500 Psi

- Filtration: dynamic @ 150 Rpm

- Test Duration: 3 or 17 hours

After the mud filtration phase the permeability to Isopar L is again measured, flowing in the production direction, using the same flow rates as used to measure the initial permeability. As back-flow is imposed, a peak in the pressure is observed which appears to correlate with cake rupture, Browne and Smith [1] and Bailey et al [3]. This pressure peak has been used by some authors as an explicit value to signify the reservoir drawdown needed to initiate flow through the drilling fluid filter-cake, Browne and Smith [1] and Alfenore et al [4]. Others use the difference in peak pressure with the equilibrium flowing pressure in the damaged core and define this as the flow initiation pressure, Bailey et al [3] and Zain and Sharma, [5]. Following Alfenore et al [4] in this paper we will use the overall pressure peak FIP peak as the drawdown needed to initiate flow from the reservoir and FIP eq as the pressure where the FIP peak is adjusted for the equilibrium Flowing Pressure Fig 1. The recovered permeability $(\%)$ is the difference between the equilibrium flowing pressures before and after the mud filtration phase and is a measure of residual damage.

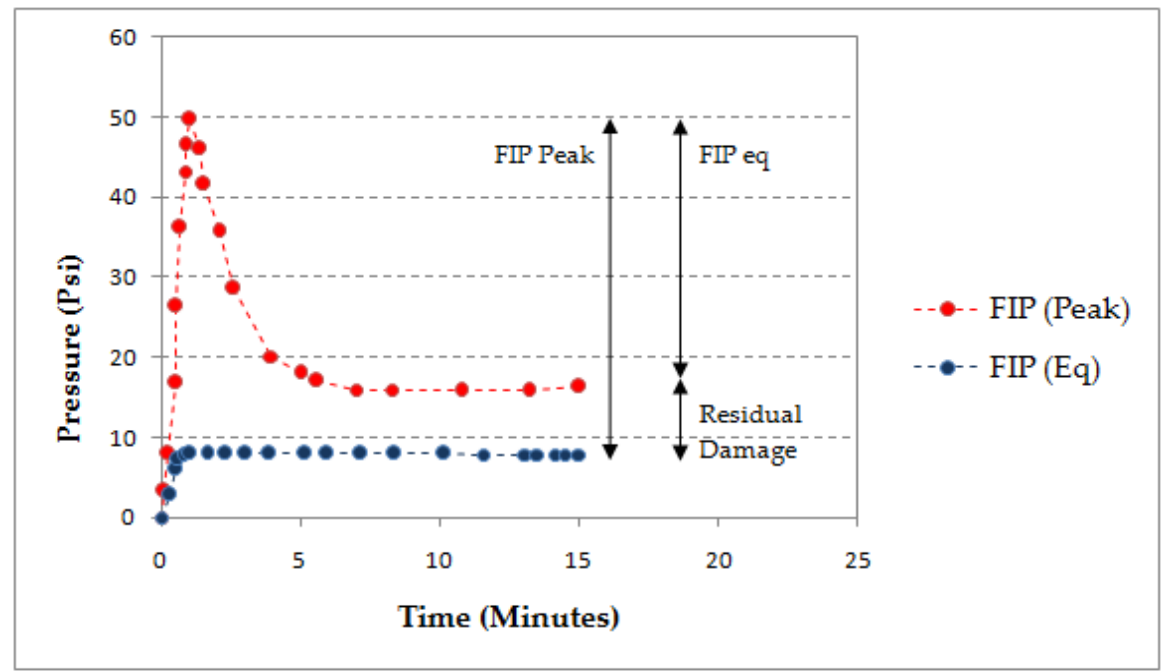

Fig. 1. Sketch of the definitions used in this paper for FIP (Peak), FIP (Eq) (equilibrium flowing pressure) and residual damage

The drilling fluid used throughout the tests was a standard OBM using a low toxicity mineral oil as the base fluid. The drilling fluid had oil: water ratio of 75:25 and mud weight of $10.53 \mathrm{ppg}$ (barite-weighted). As well as the various mud products needed to make up the fluid, synthetic drilled solid (RevDust) was added at $15 \mathrm{ppb}$ concentration Journal of Engineering Sciences, Assiut University, Faculty of Engineering, Vol. 41, No. 2, March, 2013, E-mail address: jes@aun.edu.eg 
A.E. Enbaia et al, A study of the performance and characterizations of cleanup fluids for reservoirs drilled by using oil-based muds, pp. $702-723$

Table 2. The drilling fluid had an API plastic viscosity (PV) of $31 \mathrm{c}-$ Poise and yield point (YP) of $21 \mathrm{lb} / 100 \mathrm{ft}^{2}$.

\section{Table 2}

Standard OBM formulation used throughout the study

\begin{tabular}{lc}
\hline \hline Drilling Fluids Additives & Concentration \\
\hline Base Oil & $0.60 \mathrm{bbl}$ \\
Water & $0.20 \mathrm{bbl}$ \\
Primary Emulsifier & $3.60 \mathrm{ppb}$ \\
Secondary Emulsifier & $3.60 \mathrm{ppb}$ \\
Organoclay & $6.00 \mathrm{ppb}$ \\
Gilsonite & $5.00 \mathrm{ppb}$ \\
Lime & $6.00 \mathrm{ppb}$ \\
Calcium Chloride & $35.2 \mathrm{ppb}$ \\
Barite & $12.3 \mathrm{ppb}$ \\
Rev Dust & $15.0 \mathrm{ppb}$ \\
\hline \hline
\end{tabular}

\section{Results: retained permeability vs rock permeability}

The results for the cores ranging in permeability from 5 to $7632 \mathrm{mD}$ are given in Table 3 and plotted in Fig 2. The damage from the drilling fluid is low for the lower permeability samples and in fact for the tightest cores the retained permeability is greater than $100 \%$. The very high retained permeabilities suggest that the components of the OBM are very effective in bridging the pore throats for the cores with permeability to oil of up to 1000 $\mathrm{mD}$.

For permeabilities greater than $1000 \mathrm{mD}$, we can see a significant reduction in the retained permeability figures. As the permeability of the core plugs increases, so does the pore throat diameters, and permitting greater invasion by the drilling fluid. This can lead to damage in the region of $50-60 \%$ for rock permeabilities of $5000-8000 \mathrm{mD}$. To evaluate the sensitivity of this trend with various test parameters, some of the test conditions and fluid parameters were varied.

The significance of the filtration time was evaluated by completing some tests for 17 hours as well as the standard 3 hour duration. Fig 3A shows the effect of increased time of mud filtration on the low and high permeability cores. For the low permeability cores the retained permeability was greater than $100 \%$ (i.e. core stimulated), with the 17 hour filtration test possessing a slightly higher retained permeability value than the shorter time test. For the high permeability cores there is no discernible difference between the retained permeability when 3 or 17 hours mud filtration is used. These results indicate that alteration of the rock matrix by the drilling fluid occurs in the early part of the filtration process, such as the spurt phase and that further exposure to OBM filtrate does not alter this level of damage.

Journal of Engineering Sciences, Assiut University, Faculty of Engineering, Vol. 41, No. 2, March, 2013, E-mail address: jes@aun.edu.eg 
A.E. Enbaia et al, A study of the performance and characterizations of cleanup fluids for reservoirs drilled by using oil-based muds, pp. $702-723$

The drilling fluid Oil water Ratio (OWR) was altered to evaluate whether this affected the trend of mud damage data with rock permeability. Fig 3B shows that with both low and high permeability formations, the level of retained permeability does not alter with varying the (OWR). Again, with the tighter rocks we can see that the retained permeability values are far greater than $100 \%$. In terms of bridging the pore throats, the emulsion phase of the OBM is obviously too small, so additions were made of a suitably sized calcium carbonate.

The carbonate was chosen based on the rule that the majority of the particles should be greater than one third to half the pore throat size. The results indicate that addition of 25 ppb bridging carbonate wasn't very successful in reducing the levels of damage (red circled point in Fig 2).

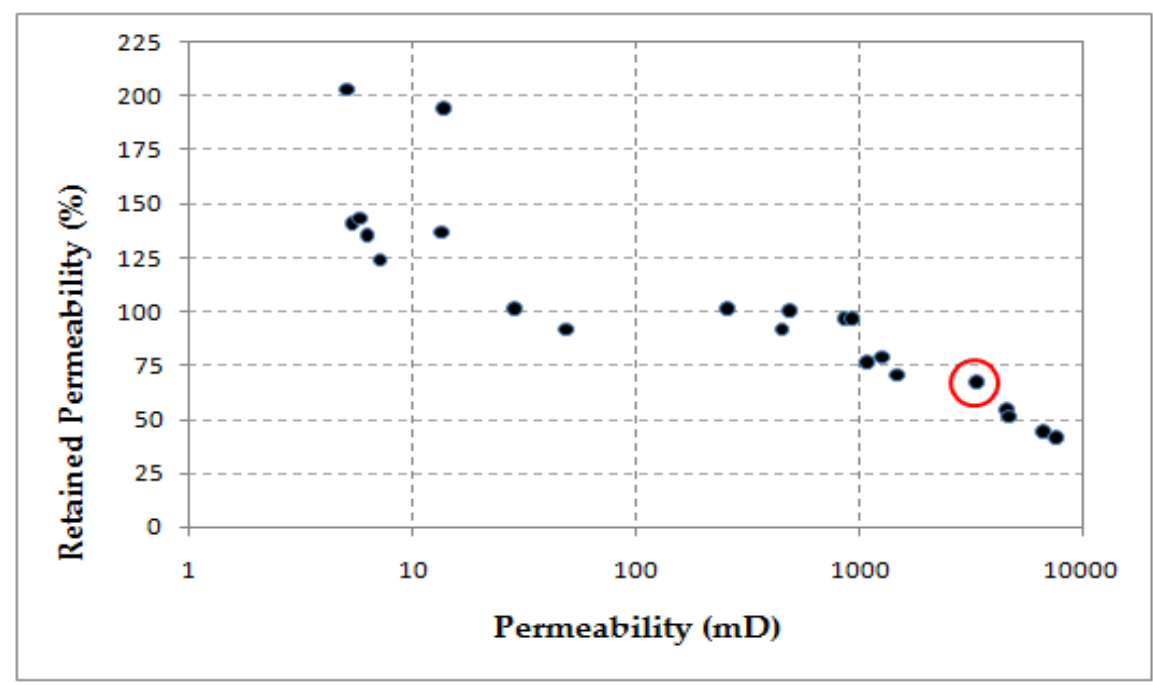

Fig. 2. Formation damage results for the OBM versus rock permeability. Point circled in red has $25 \mathrm{lb} / \mathrm{bbl}$ bridging carbonate added.

\section{Results: fip vs rock permeability}

The values for FIP peak and FIP eq are given in Table 3 and plotted in Fig 4 versus rock permeability. As found by Browne and Smith [1] and Browne et al [6], our results show that only with the lower permeability cores we do see significant levels of drawdown needed to initiate flow. For example, the condensed rock had a permeability of $5.41 \mathrm{mD}$ with a FIP peak of 131 psi. The FIP eq values are much lower (e.g. 14 psi) and this is due to the greater than $100 \%$ retained permeability after drilling fluid filtration. In these cases the equilibrium flowing pressure is always lower than the initial flowing pressure and hence when the FIP peak is corrected to derive the FIP eq, the pressure is relatively low.

Journal of Engineering Sciences, Assiut University, Faculty of Engineering, Vol. 41, No. 2, March, 2013, E-mail address: jes@aun.edu.eg 
A.E. Enbaia et al, A study of the performance and characterizations of cleanup fluids for reservoirs drilled by using oil-based muds, pp. $702-723$

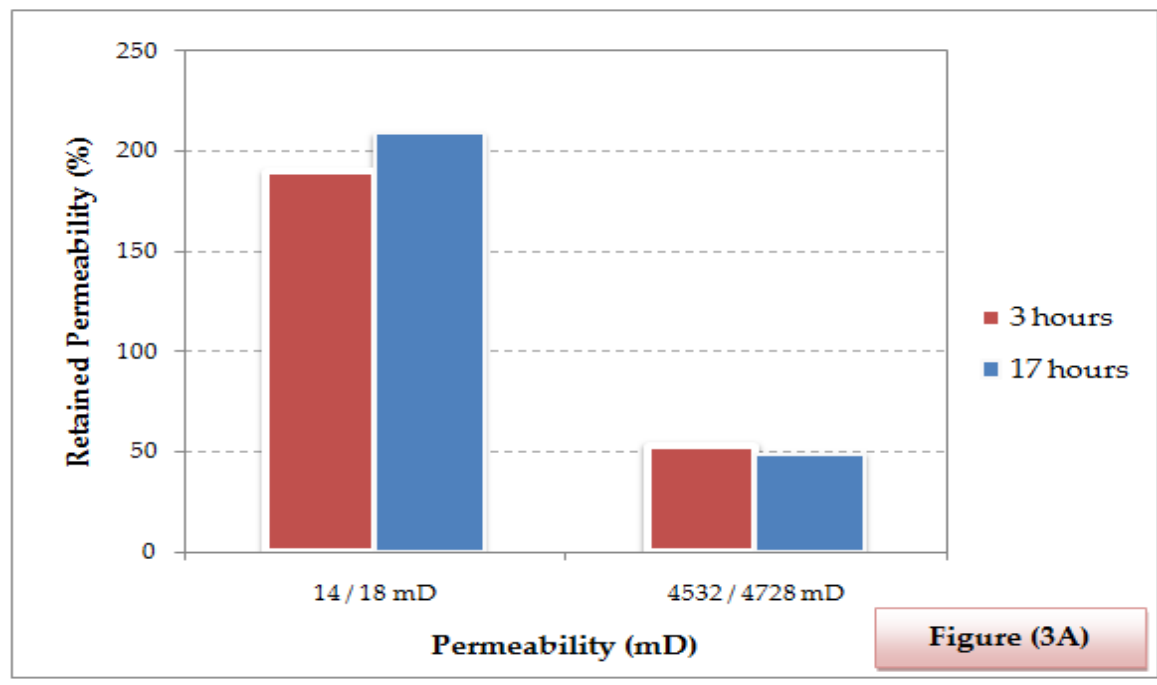

Fig. 3. (A): The effect of OBM filtration time on the levels of damage found in low and high permeability rocks

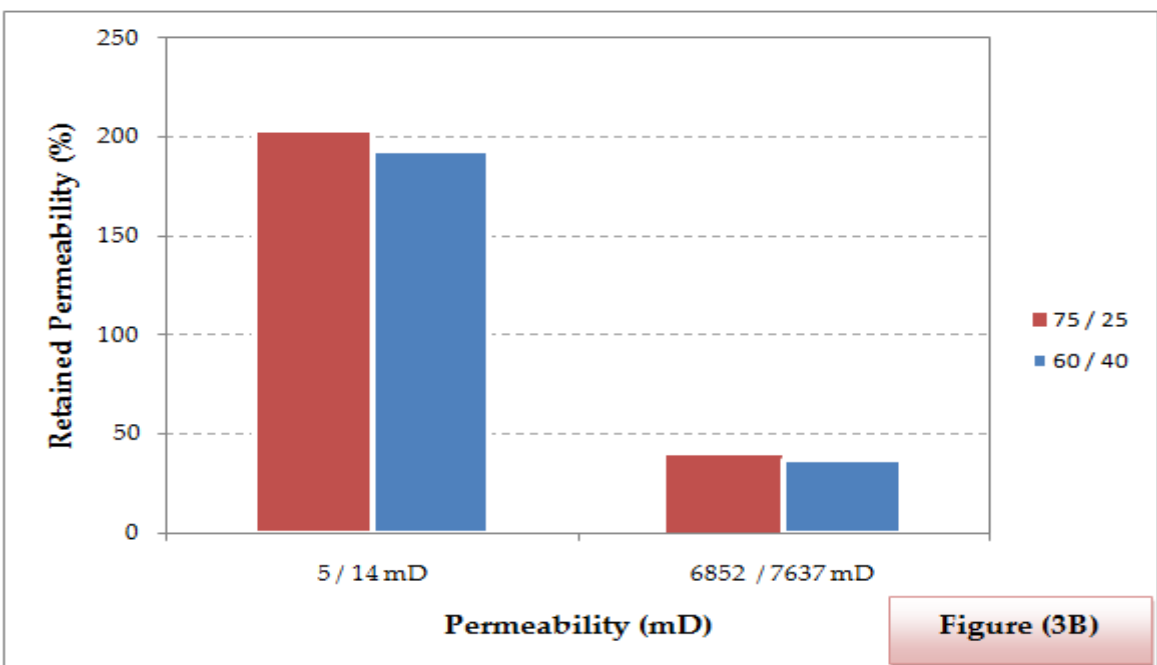

Fig. 3. (B): The effect of OBM filtration time on the levels of damage found in low and high permeability rocks

Journal of Engineering Sciences, Assiut University, Faculty of Engineering, Vol. 41, No. 2, March, 2013, E-mail address: jes@aun.edu.eg 
A.E. Enbaia et al, A study of the performance and characterizations of cleanup fluids for reservoirs drilled by using oil-based muds, pp. $702-723$

Table 3

Results for retained permeability and FIP values versus rock permeability

\begin{tabular}{|c|c|c|c|c|c|c|}
\hline $\begin{array}{l}\text { Reference } \\
\text { No. }\end{array}$ & $\begin{array}{c}\text { Permeability } \\
\text { (mD) }\end{array}$ & $\begin{array}{c}\text { Filtrate } \\
\text { Loss } \\
(\mathbf{m D})\end{array}$ & $\begin{array}{c}\text { Retained } \\
\text { Permeability } \\
(\%)\end{array}$ & $\begin{array}{c}\text { FIP } \\
\text { Peak } \\
\text { (Psi) }\end{array}$ & $\begin{array}{c}\text { FIP } \\
\text { eq } \\
\text { (Psi) }\end{array}$ & Comments \\
\hline 1 & 451 & 1.5 & 90 & 7.47 & 4.45 & $\begin{array}{c}\text { Standard } \\
\text { Conditions }\end{array}$ \\
\hline $1 \mathrm{~A}$ & 262 & 1.6 & 100 & 7.86 & 3.89 & $=$ \\
\hline 2 & 1539 & 0.9 & 68 & 2.69 & 1.04 & $=$ \\
\hline $2 \mathrm{~A}$ & 1093 & 1.3 & 74 & 2.20 & 1.00 & $=$ \\
\hline 3 & 847 & 1.4 & 95 & 3.64 & 1.97 & $=$ \\
\hline $3 \mathrm{~A}$ & 481 & 1.7 & 99 & 8.03 & 4.43 & $=$ \\
\hline 4 & 1288 & 2.2 & 78 & 3.51 & 2.15 & $=$ \\
\hline $2 \mathrm{~B}$ & 934 & 1.4 & 94 & 4.15 & 2.56 & $=$ \\
\hline 5 & 4532 & 2.5 & 52 & 1.49 & 1.01 & $=$ \\
\hline 6 & 51.8 & 1.7 & 91 & 40.9 & 10.4 & $=$ \\
\hline $6 \mathrm{~A}$ & 29.0 & 1.4 & 99 & 54.9 & 5.42 & $=$ \\
\hline $7 \mathrm{~B}$ & 5.41 & 1.6 & 139 & 131 & 14.2 & $=$ \\
\hline $7 \mathrm{C}$ & 6.95 & 1.3 & 123 & 114 & 10.6 & $=$ \\
\hline A & 7637 & 1.7 & 39 & 2.03 & 1.51 & $=$ \\
\hline B & 6852 & 3.0 & 41 & 1.23 & 1.42 & $=$ \\
\hline $\mathrm{V}$ & 14.03 & 1.6 & 191 & 1.16 & 24.6 & $=$ \\
\hline $\mathrm{E}$ & 4728 & 3.4 & 48 & 2.87 & 1.45 & $\begin{array}{l}17 \text { hours } \\
\text { Filtration }\end{array}$ \\
\hline W & 17.81 & 2.2 & 209 & 83 & 18.7 & $\begin{array}{l}17 \text { hours } \\
\text { Filtration } \\
25 \mathrm{ppb}\end{array}$ \\
\hline $\mathrm{C}$ & 3226 & 1.5 & 66 & 2.81 & 1.56 & $\begin{array}{c}\text { Calcium } \\
\text { Carbonate } \\
\end{array}$ \\
\hline
\end{tabular}

For the lower permeability rocks (i.e. $<100 \mathrm{mD}$ ) we can see that the FIP peak has a very clear trend with the permeability of the core plug and that this is an order of magnitude greater than the FIP eq for a given permeability. There is also more scatter to the data due to the variability in the FIP eq value with the varying levels of retained permeability (i.e. the equilibrium flowing pressure). The laboratory results reported here compare very favorably with FIP peak results reported in Browne et al [6] for field OBM evaluated with various core permeabilities. Their data showed that tighter rocks have far higher FIP peak values than more permeable formations and the values compare very well with those reported in this paper.

Journal of Engineering Sciences, Assiut University, Faculty of Engineering, Vol. 41, No. 2, March, 2013, E-mail address: jes@aun.edu.eg 




Fig. 4. FIP values for the OBM filter cake versus core permeability

\section{Results: filtrate volume vs rock permeability}

For all the tests, the mean fluid loss across the full permeability range was $1.66 \mathrm{ml}$ with a standard deviation of $0.49 \mathrm{ml}$. The volume of filtrate collected during the mud filtration does not change below $1000 \mathrm{mD}$ in permeability, but above this there is greater fluid loss indicating the poorer bridging performance as indication (Figure 5). Changing the mud filtration time from 3 to 17 hours on both $14-18 \mathrm{mD}$ and $4532-4728 \mathrm{mD}$ rock substrates results in higher fluid loss, as expected from Darcy's Law, but not a change in the formation damage or FIP peak values. Also, the same drilling fluid which had the sized calcium carbonate added reduced the fluid loss compared to the tests using cores of similar permeability with the standard mud formulation. However, the formation damage for these tests was very similar. This shows that the early time behavior of the filtration phase, i.e. the spurt loss, controls the performance of the mud in terms of damage and flow-back properties. It appears that for these tests the overall fluid loss of the OBM does not play a major role in the damage imparted by the fluid which is not the case with WBM formulations Alfenore et al [4].

Journal of Engineering Sciences, Assiut University, Faculty of Engineering, Vol. 41, No. 2, March, 2013, E-mail address:jes@aun.edu.eg 
A.E. Enbaia et al, A study of the performance and characterizations of cleanup fluids for reservoirs drilled by using oil-based muds, pp. $702-723$

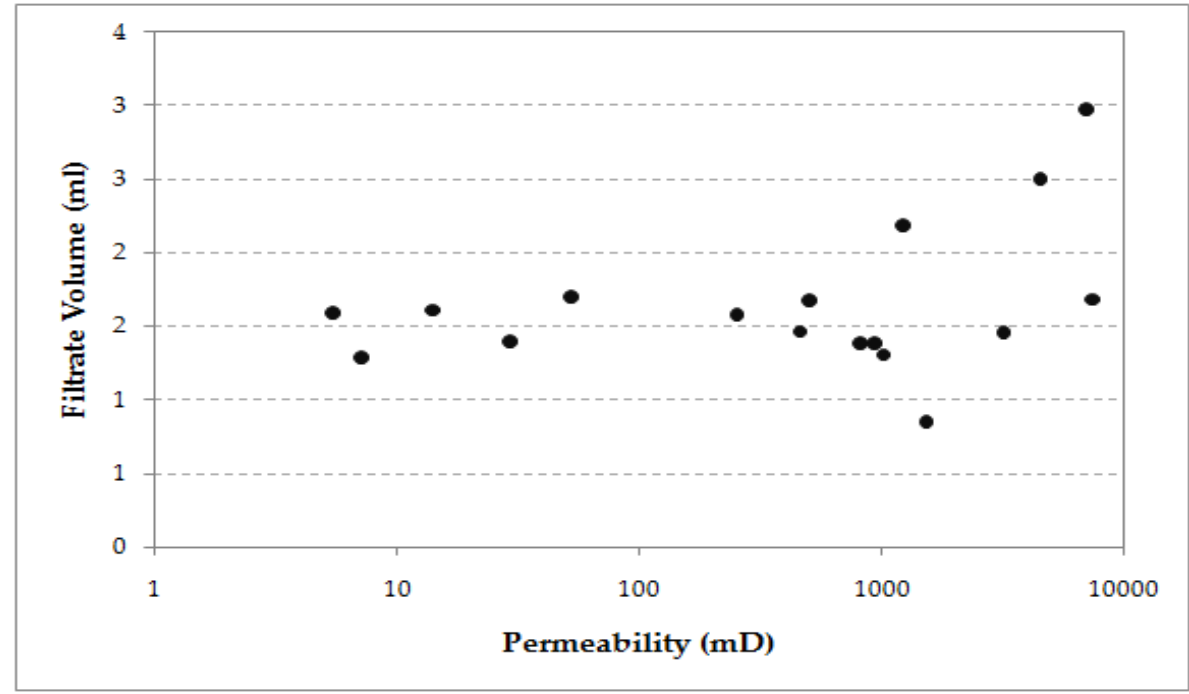

Fig. 5. OBM filtrate volumes versus rock permeability

\section{Discussion of damage and FIP vs rock permeability}

Studies of FIP values for WBM have found a number of factors including the solids volume fraction, the particle size of the solids, the mineralogy of the solids, the rock permeability and the filtration pressure are all important, Bailey et al [3] and Zain and Sharma [5]. Mud type also plays an important role in the behavior of the filter-cake when exposed to fluid flow, with FIP values for OBM being less than WBM values, Browne and Smith [1] ; Alfenore et al [4] and Browne et al [6]. For example, FIP values of WBM can depend on the flocculation state of the bentonite mud as well as the concentration of polymers. The results reported here are for one mud type across a range of core permeabilities, however, the match with data from, Browne et al [6] is very good.

Interpreting the formation damage and FIP peak results together, we can see that for wellbores intersecting heterogeneous reservoirs with a range of producing horizon permeabilities, an OBM will give rise to invasion and damage in the high permeability formations, whereas at lower permeabilities the damage is relatively low. The FIP peak needed to initiate production counterbalances these results, where high pressures will be needed to initiate flow through the filter-cake in the undamaged lower permeability horizons. For the high permeability horizons, the FIP peak will be relatively low but the damage quite high. In these tests we have found damage up to 50-60\% which according to modeling of reservoir inflow performance for horizontal wellbores can lead to significant reduction in the reservoir inflow performance, Browne and Smith [1] and Burton and Hodge [7].

Journal of Engineering Sciences, Assiut University, Faculty of Engineering, Vol. 41, No. 2, March, 2013, E-mail address: jes@aun.edu.eg 
A.E. Enbaia et al, A study of the performance and characterizations of cleanup fluids for reservoirs drilled by using oil-based muds, pp. $702-723$

The reasons for this variability in the damage and FIP $\mathrm{eq}_{\text {e }} / \mathrm{FIP}_{\text {peak }}$ profile are related to both drilling fluid and core matrix effects. In the tighter rocks relative permeability effects are largely what control the flow of fluid through the matrix, Ladva et al [2]. The loss of filtrate into the formation affects the phase saturation of the core plug and greater oil saturation leads to a relative increase in rock permeability. That is why in the tests reported here using the tight core plugs we found $>100 \%$ return permeability each time. It is the flow characteristics and relative permeability effects which give the increased permeability of the rock matrix. For the higher permeability rocks the matrix effects and the saturation levels are not as important and the cake characteristics assume greater influence on the FIP value rather than the rock matrix. The yield stress of OBM filter-cakes is low and hence the FIP required to initiate flow is low.

A caveat to these results is that the high FIP values were always measured to oil as the flowing medium. For tight formations containing gas we don't know what affect this has in terms of the multiphase flow and how gas FIP values would compare to the oil FIP values. This is an obvious area for future research.

\section{Cleanup fluids for OBM}

Within the context of minimizing skin for the completed reservoir interval, the displacement and cleanup phase can be critical to achieving this aim, Alfenore et al [4]. We have demonstrated above that if an OBM is used for drilling a horizontal reservoir section where the reservoir permeability is heterogeneous, we can have the scenario where inflow only occurs from the higher permeability, relatively badly damaged, horizons. As noted by (Browne and Smith 1994) who used reservoir inflow modeling, it is far better in terms of productivity to produce from as large a section as possible of the wellbore, even if it is badly damaged (e.g. 60\%), than producing from a smaller area of undamaged reservoir. We therefore decided to evaluate some displacement/cleanup fluids for application to the filter-cake in those areas of the reservoir where high FIP values could exist.

\section{Experimental methods: screening of fluids}

To screen a variety of solutions for applications in displacement / cleanup of OBM in the reservoir we adopted a lab developed procedure. The technique utilizes an oilfield viscometer rotor coated in sand to which mud adheres. The mud removal efficiency of various combinations of solvents, surfactants and dispersants can be evaluated. It is anticipated that the combinations of chemicals which are effective in mud removal could also be applied as a breaker to weaken the OBM filter-cake.

\section{Results: cleanup fluid efficiencies}

Prior to evaluating a suite of cleanup chemicals, a series of tests considered the affect of certain mud parameters on the removal efficiencies. Some of the mud parameters evaluated included base oil type, oil: water ratio and emulsifier content. It is difficult to change the mud parameters mentioned above without influencing other mud properties, but attempts

Journal of Engineering Sciences, Assiut University, Faculty of Engineering, Vol. 41, No. 2, March, 2013, E-mail address: jes@aun.edu.eg 
A.E. Enbaia et al, A study of the performance and characterizations of cleanup fluids for reservoirs drilled by using oil-based muds, pp. $702-723$

were made to limit the inter-fluid variation in viscosity, solids volume fraction, etc. For cleanup fluid B (blend of organic solvents and surfactants) the results in Fig 6 A and B show that base oil type and oil: water ratio significantly affect the mud removal efficiency. Where the emulsifier content of the mud was varied, the cleanup efficiency of fluid A (2\% surfactants and dispersants in base oil) was not affected, however, for fluid B the rate of removal was significantly slower Fig 7.

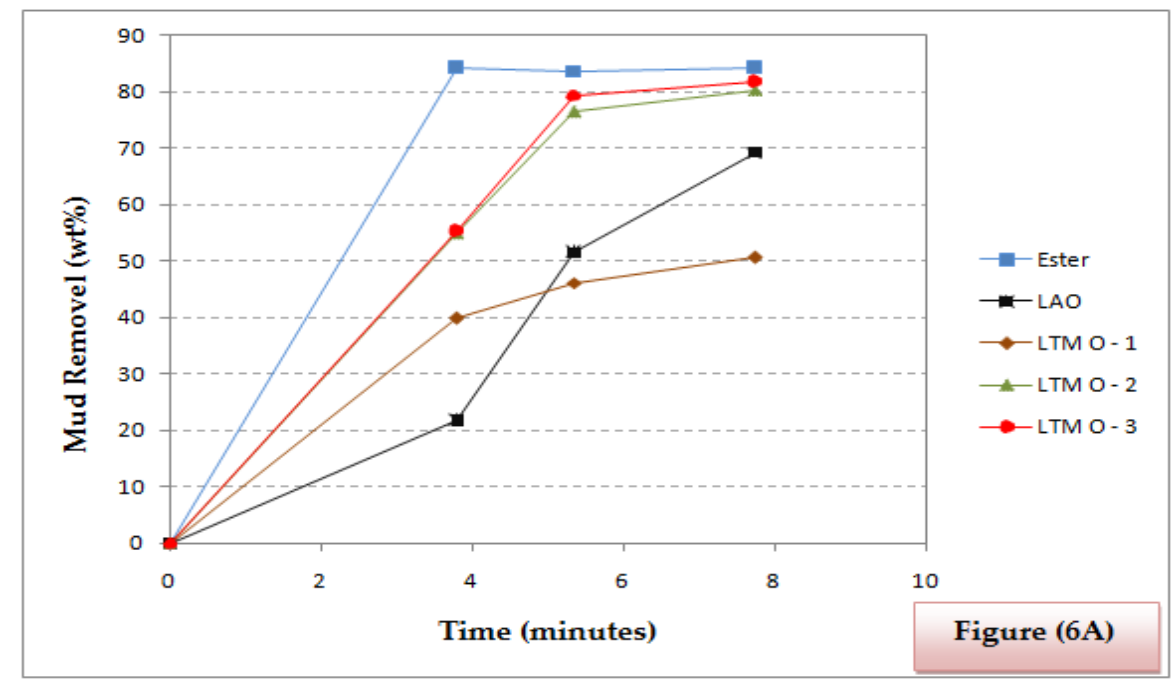

Fig. 6. (A): The effect of base oil-type on OBM removal efficiency for cleanup fluid B.

The cleanup efficiencies of a variety of combinations of surfactants, solvents and dispersants were appraised using the sand-rotor coated in the OBM utilized throughout the formation damage/FIP tests discussed above. The results in Figure 8 show that the rate and overall removal efficiency, as well as the wettability state, is variable depending on the combinations of the various chemicals. What became apparent from the tests was that achieving a surfactant induced change in wettability state from that of the carrying base fluid was very difficult Table 4. An intermediate state between oil- and water-wet was the best outcome we found. Much better removal and change in wettability was achieved when two stages were employed. The two fluids chosen for further evaluation for FIP peak reduction tests were fluids $\mathrm{A}$ and $\mathrm{B}$; the former based on these test results and the latter from both the performance here and successful field applications.

The switching of wellbore wettability state is an important consideration for displacement in horizontal wells utilizing sand control screens where a water-based gravel pack carrier fluid is used. The more complete change in the wettability state, the less the chance of forming emulsion blocks in the formation and completion. It would appear prudent to use

Journal of Engineering Sciences, Assiut University, Faculty of Engineering, Vol. 41, No. 2, March, 2013, E-mail address: jes@aun.edu.eg 
A.E. Enbaia et al, A study of the performance and characterizations of cleanup fluids for reservoirs drilled by using oil-based muds, pp. $702-723$

an oil-based solvent to remove as much of the OBM as possible and then apply a waterwetting fluid phase.

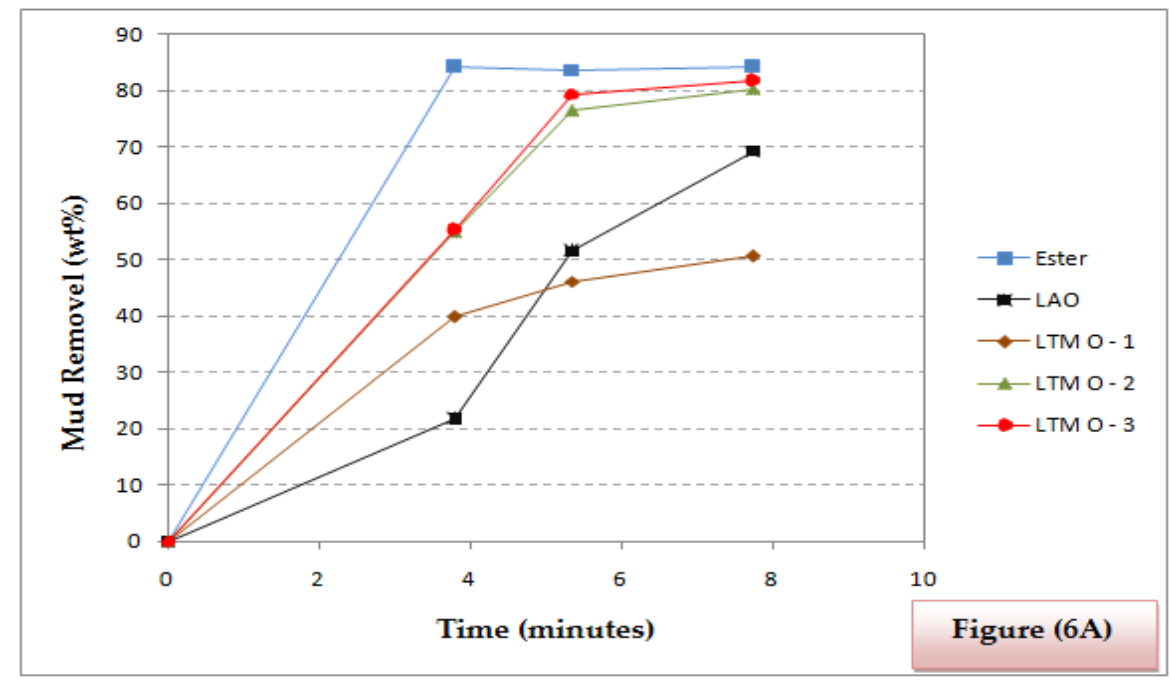

Fig. 6. (A): The effect of base oil-type on OBM removal efficiency for cleanup fluid B.

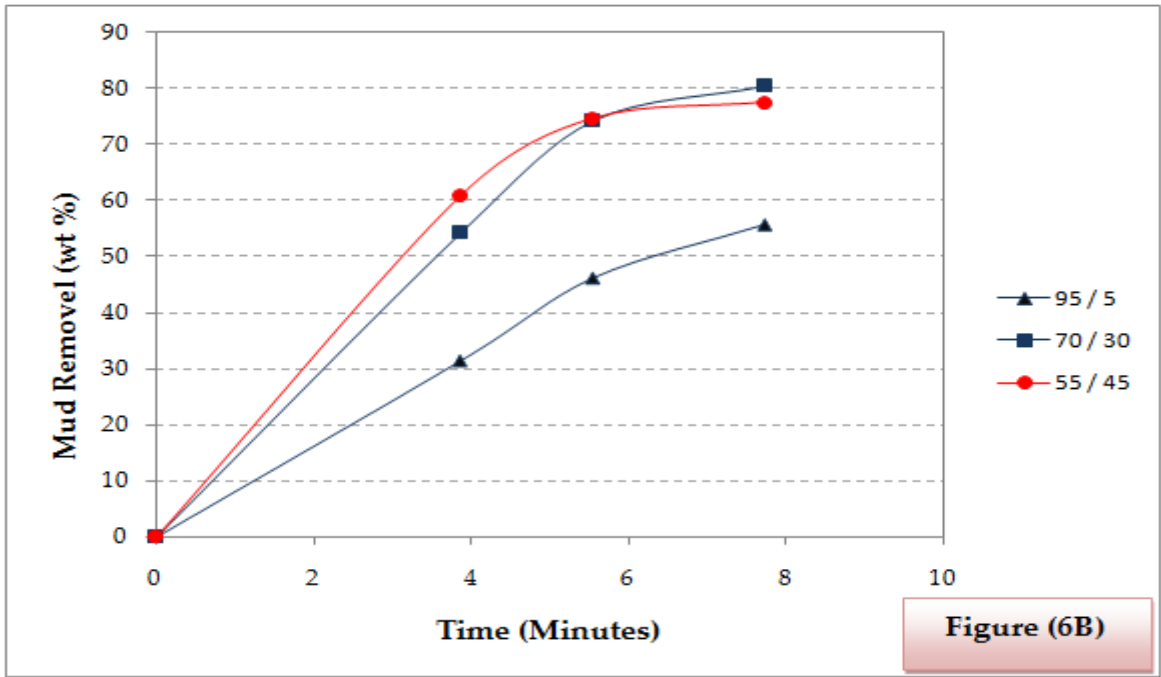

Fig. 6. (B): The effect of oil: water ratio on OBM removal efficiency for cleanup fluid B.

Journal of Engineering Sciences, Assiut University, Faculty of Engineering, Vol. 41, No. 2, March, 2013, E-mail address: jes@aun.edu.eg 
A.E. Enbaia et al, A study of the performance and characterizations of cleanup fluids for reservoirs drilled by using oil-based muds, pp. $702-723$

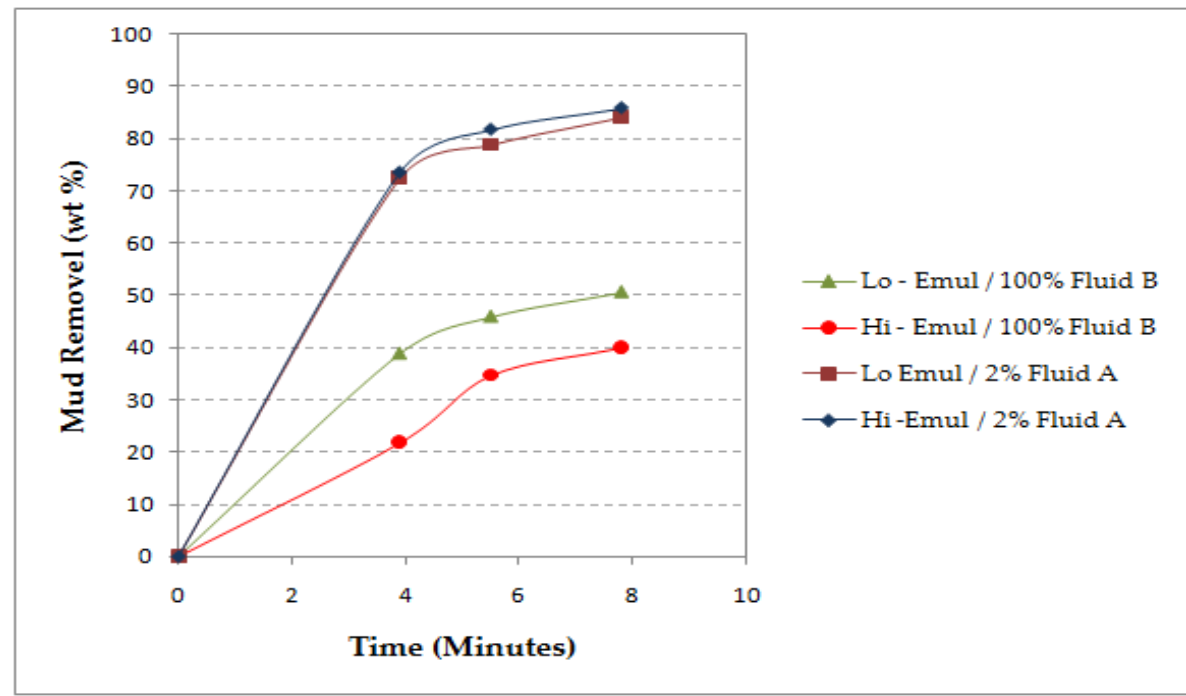

Fig. 7. The effect of emulsifier content on OBM removal efficiency for cleanup fluid $\mathrm{A}$ and $\mathrm{B}$

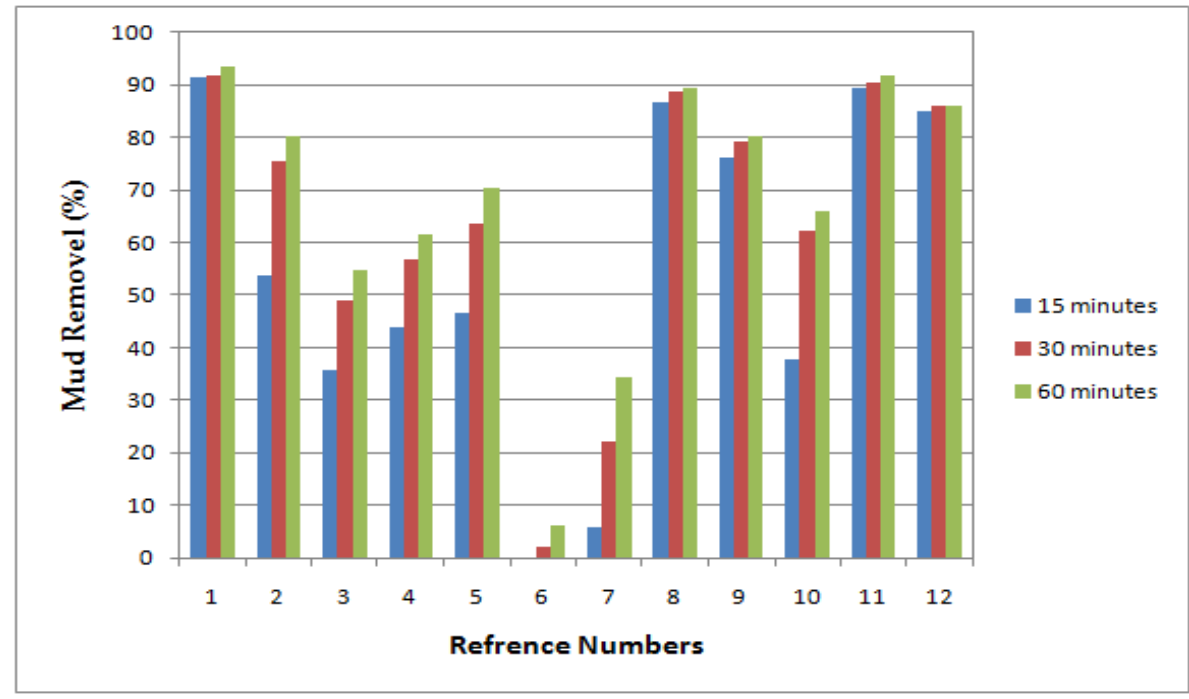

Fig. 8. Results of the screening tests for suitable OBM cleanup fluid chemistry. Xaxis reference numbers refer to fluid chemistry in table 4.

Journal of Engineering Sciences, Assiut University, Faculty of Engineering, Vol. 41, No. 2, March, 2013, E-mail address: jes@aun.edu.eg 
A.E. Enbaia et al, A study of the performance and characterizations of cleanup fluids for reservoirs drilled by using oil-based muds, pp. $702-723$

\section{Table 4}

Chemicals and base fluids used in the screening of cleanup fluids for mud removal. Reference numbers related to those used in figure 8 above.

\begin{tabular}{|c|c|c|c|}
\hline 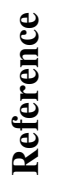 & $\begin{array}{l}\text { Base } \\
\text { Fluid }\end{array}$ & Chemicals and Concentration (Volume \%) & $\begin{array}{c}\text { Wettability } \\
\text { State }\end{array}$ \\
\hline 1 & Base Oil & Surfactant blend A (2\%) & Intermediate \\
\hline 2 & None & Solvent / Surfactant blend B (100\%) & Oil-wet \\
\hline 3 & Water & Mutual Solvent $(3 \%)+$ Surfactant A $(0.2 \%)$ & Water-wet \\
\hline 4 & Water & Mutual Solvent $(5 \%)+$ Surfactant A $(0.5 \%)$ & Water-wet \\
\hline 5 & Water & Mutual Solvent $(5 \%)+$ Surfactant B $(0.5 \%)$ & Water-wet \\
\hline 6 & Water & Surfactant A $(0.5 \%)+$ Surfactant C $(1 \%)$ & Water-wet \\
\hline 7 & Water & Surfactant B $(0.5 \%)+$ Surfactant C $(1 \%)$ & Water-wet \\
\hline 8 & Base Oil & Organic Solvent ( $5 \%)$ & Oil-wet \\
\hline 9 & Base Oil & Organic Solvent ( $3 \%$ ) & Oil-wet \\
\hline 10 & Water & Surfactant blend C (2\%) & Water-wet \\
\hline 11 & Base Oil & Organic Solvent $(2 \%)+$ Surfactant blend C (2\%) & Oil-wet \\
\hline 12 & Base Oil & Organic Solvent (2\%) & Oil-wet \\
\hline 12 & Water & Surfactant blend C (2\%) & Water-wet \\
\hline
\end{tabular}

\section{Reduction of OBM filter-cake FIP}

\subsection{Experimental methods}

If we consider reservoirs where the drawdown pressure for the flowing interval is low and less than the FIP peak for a mud applied to that formation, then some form of a cleanup fluid would be required. The results presented here and discussed in other papers, Browne and Smith [1]; Bailey et al [3]; Zain and Sharma [5], and Browne et al [6] show that it is more than likely the low permeability horizons which will not have sufficient drawdown to initiate flow through the filter-cake. We describe here a series of tests which evaluated whether the cleanup fluids found to be effective in mud removal could also be used to lower the FIP peak needed to initiate flow through the cake.

To achieve this goal, another series of core tests were completed. After the mud filtration phase, another phase of exposure of the mud filter-cake and core to a cleanup fluid was made. The core material used for this part of the study was Birchover Sandstone which had relatively low permeabilities $(\sim 5-18 \mathrm{mD})$ and consequently relatively high FIP values. The measurement of the core permeability was made at an imposed constant flow rate of 4 $\mathrm{ml} / \mathrm{min}$. The mud filtration phase was the same as the formation damage/FIP evaluations

Journal of Engineering Sciences, Assiut University, Faculty of Engineering, Vol. 41, No. 2, March, 2013, E-mail address: jes@aun.edu.eg 
A.E. Enbaia et al, A study of the performance and characterizations of cleanup fluids for reservoirs drilled by using oil-based muds, pp. $702-723$

discussed earlier in this paper. After the mud filtration phase the cleanup fluid was applied under the following conditions:

- Temperature: $180^{\circ} \mathrm{F}$

- Differential Pressure: 0 psi or 100 psi

- Filtration: static

- Time: 3 or 17 hours

The retained permeability and FIP peak were measured after exposure to the cleanup fluid to gauge their impact on these values. Two cleanup fluids were evaluated, Fluid A consisting of a blend of surfactants, solvents and dispersants which were mixed at $2 \% \mathrm{v} / \mathrm{v}$ into a base oil. Fluid B was a $100 \%$ solution of organic solvent and surfactants

\section{Results: reduction of OBM filter-cake FIP}

The results for Fluid A Fig 9 show that all three tests conducted at balanced soak conditions produced significantly lower FIP peak values. Little difference was found between the 3 and 17 hours of exposure. For the one test conducted with 100 psi differential pressure and 3 hour soak period, there appears to be no reduction in the FIP peak. The results for Fluid B Figure 9 show that for the tests conducted at balanced pressure conditions the 17 hours exposure produced the largest reduction in the FIP peak. For both fluids tested where an overbalance pressure of 100 psi was applied, either for 3 or 17 hours, all the filter-cakes had the lowest reduction in the FIP peak and had similar values to those tests where no cleanup fluid was applied.

If we take the data for the tests where the mud filtration was conducted without any application of a cleanup fluid and plot the permeability versus FIP peak, we see there is a very good fit of the relationship using a polynomial function (see Fig 9, R2 = 0.92). For the tests where cleanup fluids were applied we derive an actual FIP peak which can then be compared to a predicted FIP peak using the polynomial function which corrects the FIP peak for the specific core permeability. By comparing these two values, we can calculate the $\%$ reduction in the FIP peak due to the cleanup fluid. For the given conditions examined in these tests, reductions in FIP peak for low permeability formations can be reduced by $25-40 \%$ Fig 10.

The results show that a differential pressure during the soak period might be deleterious to the overall aim of FIP peak reduction. Also, for fluid B (i.e. 100\% 'active' compared to $2 \%$ for fluid A) the best result was achieved for the longest soak period prior to flowing in the production direction. This suggests for certain types of cleanup fluids, the soak period is important to allow diffusion into the filter-cake to permit the weakening of the structure.

In terms of regained permeability, the cleanup fluids do not really change the overall values compared to the tests where no cleanup fluids were applied Fig 11. As mentioned earlier, the mud filtration through the low permeability core plugs results in a relative increase in the permeability.

Journal of Engineering Sciences, Assiut University, Faculty of Engineering, Vol. 41, No. 2, March, 2013, E-mail address: jes@aun.edu.eg 
A.E. Enbaia et al, A study of the performance and characterizations of cleanup fluids for reservoirs drilled by using oil-based muds, pp. $702-723$
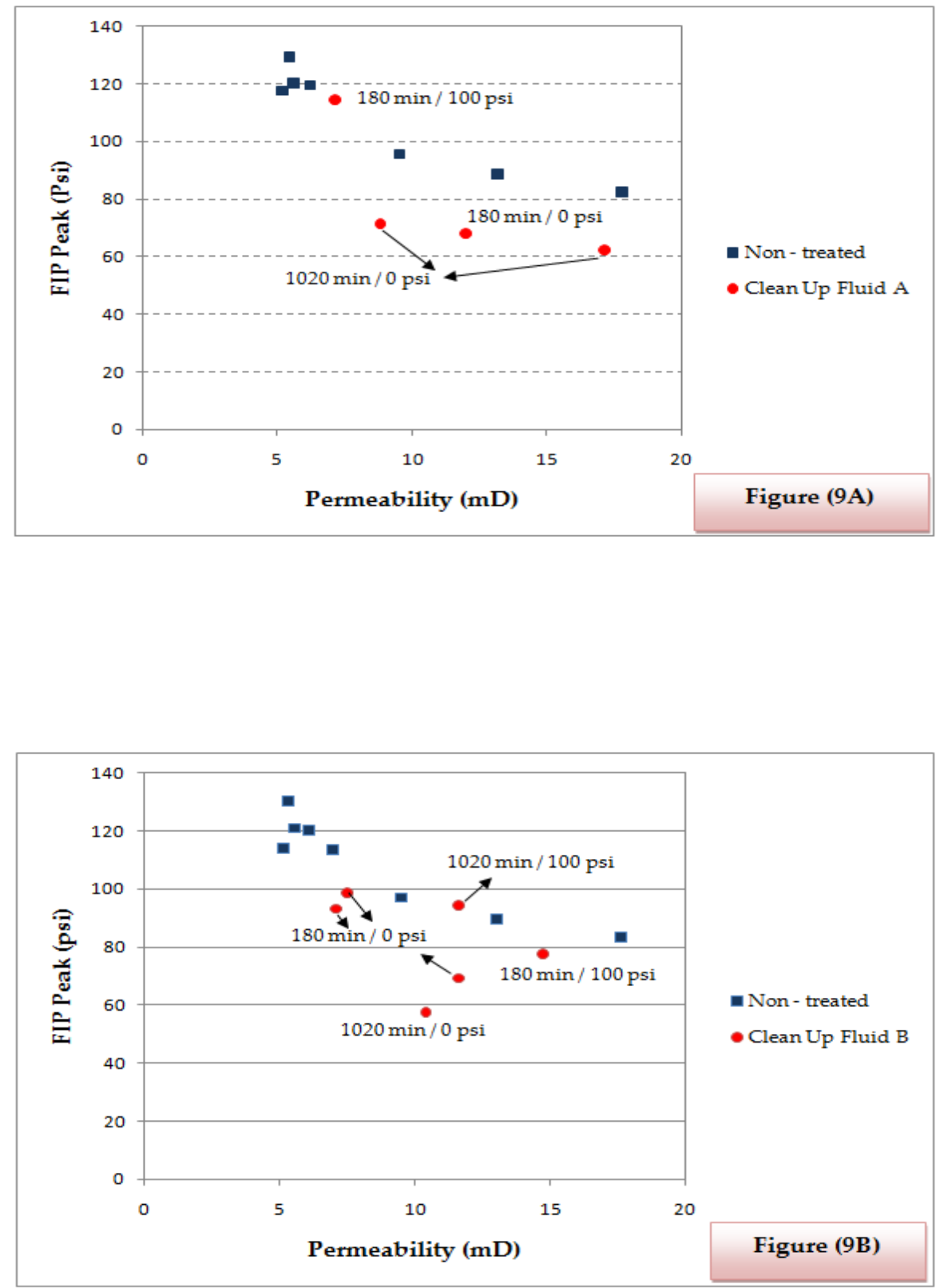

Fig. 9. Results for cleanup fluids (A) showed in figure 9A above and fluid (B) shown in figure $9 \mathrm{~B}$ above in terms of their ability to lower the FIP peak of the OBM filter cake.

Journal of Engineering Sciences, Assiut University, Faculty of Engineering, Vol. 41, No. 2, March, 2013, E-mail address: jes@aun.edu.eg 
A.E. Enbaia et al, A study of the performance and characterizations of cleanup fluids for reservoirs drilled by using oil-based muds, pp. $702-723$

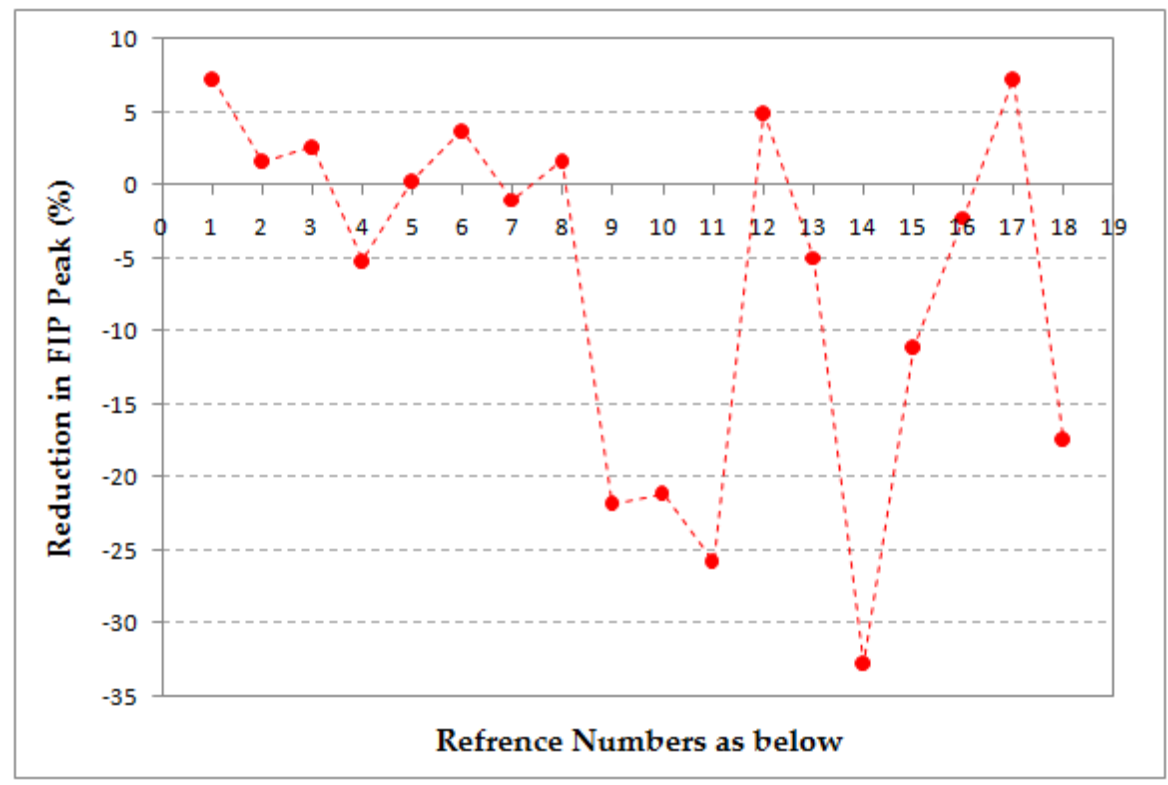

Fig. 10. Reduction in filter cake FIP peak due to application of cleanup fluids A and B under different conditions (NB. FIP peak corrected for permeability variations). Key as shown below



Journal of Engineering Sciences, Assiut University, Faculty of Engineering, Vol. 41, No. 2, March, 2013,E-mail address: jes@aun.edu.eg 
A.E. Enbaia et al, A study of the performance and characterizations of cleanup fluids for reservoirs drilled by using oil-based muds, pp. $702-723$



Fig. 11. Retained permeability values for the cleanup fluid tests using fluids $A$ and $\mathrm{B}$. The key to the $\mathrm{X}$-axis reference numbers is as above in figure 10

The application of the cleanup fluid appears to introduce more variability to the regained permeability values, with some lower and some higher. There are no trends in the formation damage data for those tests where an overbalance pressure was applied relative to those conducted at balance pressure conditions. Alfenore et al [4] actually found that application of chemical breakers with an overbalance pressure to OBM filter-cakes was deleterious to the regained permeability values.

\section{General discussion}

For the OBM formation damage tests, it was noted that above about $1000 \mathrm{mD}$ the mud induced damage increased dramatically. Similarly, the plot of the filtrate volume versus rock permeability shows an increase in filtrate above about $1000 \mathrm{mD}$. However, the tests for the extended period of filtration time do not show an increase in the levels of damage. Interpreting these results together, we can say that the initial spurt loss of the fluid is the damaging phase and that further fluid loss of the oil filtrate does not change the level of damage imposed by the drilling fluid.

The obvious way to lower the spurt loss of the OBM on high permeability substrates is to improve its bridging properties by adding a suitably sized material, such as calcium carbonate. This is certainly possible for an OBM and has been proven to be effective in lab tests, Alfenore et al [4] although a relatively large scatter of the data was found around the overall trend. The same paper also demonstrated that there was not a clear relationship between magnitude of overbalance and the subsequent damage. The bridging characteristic

Journal of Engineering Sciences, Assiut University, Faculty of Engineering, Vol. 41, No. 2, March, 2013, E-mail address: jes@aun.edu.eg 
A.E. Enbaia et al, A study of the performance and characterizations of cleanup fluids for reservoirs drilled by using oil-based muds, pp. $702-723$

of a fluid depends on the size and concentration of the particulates. With OBM there is often a considerable concentration of emulsion droplets which are in the sub- to few micron size ranges and will skew the overall particle size of the bridging material. This has little impact on the lower permeability rocks; however, for high permeability rocks where effective bridging is needed to minimize the spurt loss, this is an important facet to consider.

The results reported in this paper, where we found that the cleanup fluids were only effective for lowering the FIP when no overbalance pressure was applied, was somewhat counterintuitive. Following Darcy's Law of flow, under a pressure gradient it would be expected that the cleanup fluid would permeate into the filter cake and possibly the core, depending on the time period. Admittedly, applying an overbalance pressure would lead to OBM filter cake compaction, thereby reducing the 'void ratio' Sherwood and Meeten [8] and hence the permeability of the cake matrix. Sherwood and Meeten [8] reported profiles of void ratios within WBM cakes and OBM could be expected to follow similar trends. Just as compaction of the filter cake occurs when an overbalance pressure is applied, swelling or expansion of the filter cake will occur when this pressure is released. The result would be an increase in the void ratio of the filter cake, with the fluid in contact with the cake being imbibed, i.e. the cleanup fluid. Also, it is envisaged that the less compacted nature of the cake will aid the diffusion of chemical species into the filter cake matrix.

To limit the damage from the completion phase of a reservoir drilled with an OBM will also require suitable engineering of the displacement fluids and procedures. The aim of the displacement should be to remove as much of the mud as possible, especially the interfacial area between the filter cake and the mud, whilst maintaining the filter cake integrity. Various physical tests and modeling of this process have been made and reported in the literature, Sherwood and Meeten [8]; Sherwood et al [9] and Fordham et al [10]. These references generally recommend turbulent flow regimes for the displacement fluids to improve the hydrodynamic removal of mud and less compacted parts of the filter cake. Following the hydrodynamic removal, a shut-in and soak period at balanced pressure conditions (if possible) is recommended for diffusion based chemical interaction between the cake and cleanup fluid. This could lead to a reduction in the filter cake FIP for low permeability formations. Also, for one of the cleanup fluids tested, there is some support for the idea that diffusion with time improved the reduction in the FIP whilst for the other fluid the same reduction was achieved whether the soak was for 3 or 17 hours. There is an obvious chemical specificity to the cleanup fluid soak time required to optimize the inflow performance for low permeability rocks.

\section{Conclusions}

For the formation damage and FIP evaluations reported here using a standard OBM formulation, the following conclusions are drawn:

2. The formation damage arising from the OBM increases dramatically above $1000 \mathrm{mD}$, with damage levels up to $50-60 \%$ for rock permeabilities in the range of $5000-8000$ $\mathrm{mD}$.

Journal of Engineering Sciences, Assiut University, Faculty of Engineering, Vol. 41, No. 2, March, 2013, E-mail address: jes@aun.edu.eg 
A.E. Enbaia et al, A study of the performance and characterizations of cleanup fluids for reservoirs drilled by using oil-based muds, pp. $702-723$

3. The level of damage arising from the OBM was not found to be related to the time of drilling fluid filtration, with very similar levels of damage arising for the tests conducted for 3 and 17 hours.

4. FIP values increase dramatically below permeabilities of about $100 \mathrm{mD}$, with a FIP peak for the $5.41 \mathrm{mD}$ rock of $131 \mathrm{psi}$. All the low permeability rocks had greater than $100 \%$ retained permeability, probably due to changes in the saturation state of the rock matrix and increases in relative permeability.

5. FIP values for core plugs with greater than $300-400 \mathrm{mD}$ were all less than $10 \mathrm{psi}$.

6. The results reported here suggest that production in heterogeneous reservoirs will flow easily from the low FIP/high permeability horizons which could be relatively badly damaged. Conversely, for the relatively undamaged low permeability horizons, the drawdown pressure available might not be sufficient to exceed the filter-cake FIP and no inflow would occur from these horizons. This is of course a less than optimal scenario.

Given the last observation above, further evaluations investigated the efficacy of cleanup fluids for resolving this scenario. The conclusions drawn from this part of the study are:

7. A screening method utilized for evaluating cleanup fluid mud removal efficiencies found that mud parameters such as base oil type, emulsifier content and oil: water ratio can all play a part in the overall cleanup fluid efficiency.

8. The cleanup fluids found to be efficient in mud removal were also evaluated to gauge their effect on drilling fluid filter-cake FIP values. Using low permeability rocks, reductions in the FIP peak of $25-40 \%$ were achieved.

9. The successful application of such fluids could depend on the overbalance applied during the soak stage and also the soak time can be important for certain cleanup fluid chemistry.

\section{Nomenclature}

$\begin{array}{ll}\text { OBM } & \text { Oil Based Mud } \\ \text { WBM } & \text { Water Based Mud } \\ \text { API } & \text { American Petroleum Institute } \\ \text { FIP } & \text { Flow Initiation Pressures } \\ \text { ppg } & \text { Pounds per Gallons } \\ \text { Isopar L } & \text { Hydrocarbon Solvent } \\ \text { Ml } & \text { Millilitre } \\ \text { Min } & \text { Minutes } \\ \text { rpm } & \text { Revolution per minute } \\ { }^{\circ} \text { F } & \text { Degree Fahrenheit } \\ \text { psi } & \text { unit of measuring the pressure (Pound per Square Inch) } \\ \text { RevDust } & \text { Synthetic drilled solids } \\ \text { PV } & \text { Plastic Viscosity } \\ \text { YP } & \text { Yield Point }\end{array}$

Journal of Engineering Sciences, Assiut University, Faculty of Engineering, Vol. 41, No. 2, March, 2013,E-mail address: jes@aun.edu.eg 
A.E. Enbaia et al, A study of the performance and characterizations of cleanup fluids for reservoirs drilled by using oil-based muds, pp. $702-723$

\begin{tabular}{ll}
\hline c-Poise & Centipoises \\
$\mathrm{lb}$ & pounds \\
$\mathrm{Ft}$ & feet \\
$\mathrm{ppb}$ & Pounds per barrel \\
$\mathrm{mD}$ & milli-Darcy
\end{tabular}

\section{Acknowledgement}

The authors would like to extend thanks to their respective management for permission to publish this paper. The paper has benefited from many valuable discussions, especially with Liz Morris, Hemant Ladva, Bud Schlemmer, John Sherwood and Alan Gilmour.

\section{References}

[1] Browne, S. V, and Smith, P. S. "Mud cake Cleanup to Enhance Productivity of High Angle- Wells", SPE 27350, Lafayette, 7-10 February 1994.

[2] Ladva, H. K. J; Tardy, P. h; Howard, P. H, and Dussan, E. B. "Multiphase flow and drilling fluid filtrate effects on the onset of production", SPE58795, 2000 SPE International Symposium on Formation Damage, Lafayette, Louisiana, 22-24 February 2000.

[3] Bailey, L; Meeten, G; Way P and L. Alloret F. "Filter cake Integrity and Reservoir Damage", SPE3429, Lafayette, 18-19 February 1998.

[4] Alfenore, J; Longeron, D and Saintpere, S. "What really Matters In our Quest of Minimizing Formation Damage in Open Hole Horizontal Wells", SPE54731, The Hague, The Netherlands,

31 ay - I June 1999.

[5] Zain, Z. M. and Sharma, M. M. "Cleanup of Wall - Building Filter Cakes", SPE56635, SPE ual Technical Conference, Houston, Texas, 3-6 October 1999.

[6] Browne, S. V; Ryan, D. F; Chambers, B. D; Gilchrist, J. M and Bamforth, S. A. "Simple Approach to the Cleanup of Horizontal Wells with Prepacked Screen Completions”, JPT, September 1995.

[7] Burton, R. C, and Hodge, R. M. "The Impact of Formation Damage and Completion Impairment on Horizontal Well Productivity", SPE49097, 1998 Annual Technical Conference, New Orleans, Louisiana, 27-30 September 1998.

[8] Sherwood, J. D, and Meeten, G. H. "The filtration properties of compressible mud filtercakes", J. Petroleum Science and Engineering Vol 18, 73-81, 1997.

[9] Sherwood, J. D; Meeten, G. H; Farrow; C. A. and Alderman, N. J. "The concentration profile within non-uniform mud cakes", J. Chem. Soc. Faraday Trans., Vol 87, 611- 618, 1991.

[10] Fordham, E. J; Allen, D. F; Ladva, H. K. J. and Alderman, N. J. "The principle of critical invasion rate and its implications for log interpretation”, SPE22539, 1991 SPE Annual Technical Conference, Dallas, Texas, 6-9 October 1991.

Journal of Engineering Sciences, Assiut University, Faculty of Engineering, Vol. 41, No. 2, March, 2013, E-mail address: jes@aun.edu.eg 
A.E. Enbaia et al, A study of the performance and characterizations of cleanup fluids for reservoirs drilled by using oil-based muds, pp. $702-723$

\section{تحديد خصائص و كفاءة السوائل المستخدمة لتنظيف الطبقات

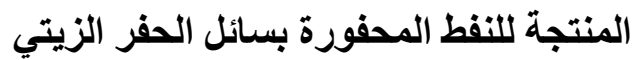

إن مسألة إختيار سائل الحفر المناسب للتكوينات النفطية يعتبر من العوامل الأساسية المهمة لضمان عدم إنهيار (أو تلف) الطبقات المنتجة للنفط.

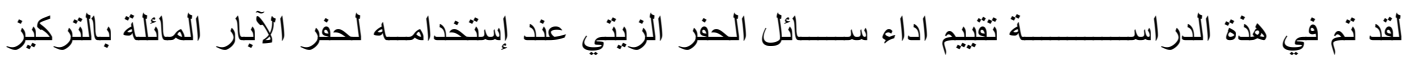

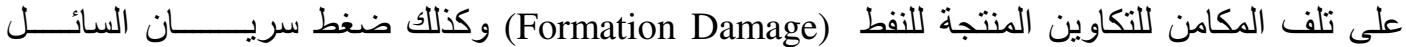
(Flow Initiation Pressure) و الناثتئة من عمليات الحفر.

لقد بينت هذة الدر اسة أن نسبة تضرر الطبقات قليلة النفاذية أثناء الحفر في صخور المكامن غير المتجانسـة

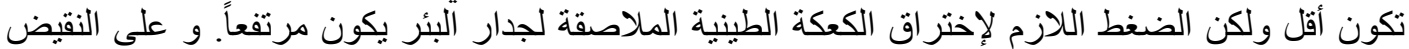

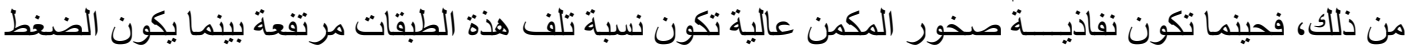

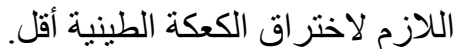

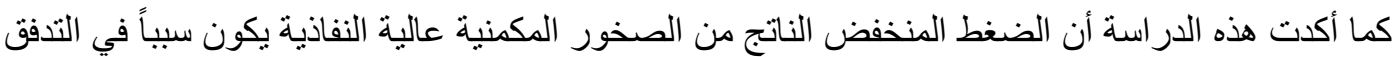



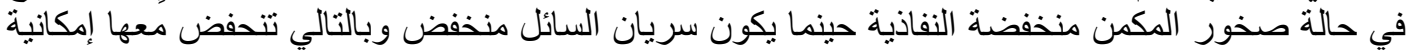
تضرر ها أو تهنكها.

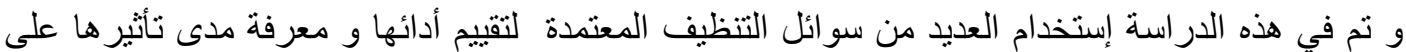
الضغط اللازم لإختر اق الطبقات الملاصقة لجدار البئر الناتجة من سائل الحفر الزيتي أثناء عمليات التهات الحفر.

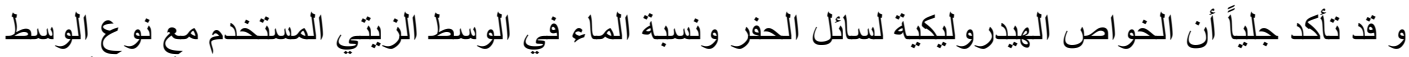


تحديد كفاءة السو ائل المستخدمة للتنظيف.

لقد تمخض عن هذه الدر اسة تحديد و إختيار أفضل السوائل لتنظيف الطبقات الملاصقة لجدار البئر، وكانت :

1. Cleanup fluid A (2\% surfactants and dispersants in base oil)

2. Cleanup fluid B (blend of organic solvents and surfactants)

وذللك بعد سلسلة إختبار ات شاملة لمجمو عة من عينات الغلاف الصخرية تمت من خلالها عملية تقييم أدائها المرتبط بتلف مثل هذة الطبقات الملاصقة لجدار البئر ومن ثم تقليل الضغط اللازم لإختر اق هذه الطبقات بما يضمن الحد من إنهيار الطبقات المنتجة.

Journal of Engineering Sciences, Assiut University, Faculty of Engineering, Vol. 41, No. 2, March, 2013,E-mail address:jes@aun.edu.eg 